\title{
VALLAN OHJAILEMAT TOIMINTAMAHDOLLISUUDET PAPERITTOMIEN MOSKOVASSA
}

\author{
Maija Kalm-Akubardia: FM, vä̈töskirjatutkija, Helsingin yliopisto
}

maija.kalm-akubardia@diak.fi

Janus vol. 29 (2) 2021, 122-140

Tiivistelmä

Tämä etnografinen tutkimus kysyy, miten ja miksi yhteiskunnan valtaeliitti ohjailee paperittomien toimintamahdollisuuksia. Kenttätyö on toteutettu Moskovassa sekä etänä 15 pitkäaikaispaperittoman kanssa vuosina 2017-2020. Tutkimuksen mukaan paperittomat ovat aktiivinen osa yhteiskuntaa ja sen kansantaloutta, mutta heidän toimintamahdollisuutensa ovat ohjailtuja ja rajoitettuja. Tutkimuksen viitekehyksenä toimivat Steven Lukesin vallan kolme ulottuvuutta (1974; 2005) sekä Martha Nussbaumin teoria toimintamahdollisuuksista (2011). Lukesin valtateorian mukaisesti paperittomien toimintamahdollisuuksien ohjailu tapahtuu päätöksenteossa, päätöksien tekemättä jättämisessä sekä yhteiskunnallisen mielipidevaikuttamisen kautta. Tutkimus löytää yhtymäkohtia Steven Lukesin valtateorian $(1974 ; 2005)$ sekä Martha Nussbaumin toimintamahdollisuuksien teorian (2011) välillä. Valtaeliitit hyötyvät harmaata taloutta ruokkivan paperittomuusilmiön ylläpitämisestä, politisoinnista ja kriminalisoinnista. Paperittoman toimintamahdollisuudet nähdään tutkimuksessa ratkaisemattomana ihmisoikeuskysymyksenä.

\section{JOHDANTO}

Arvioiden mukaan sekä EU:n että Venäjän väestömäärät laskevat. Tarve työvoimalle kasvaa ja tähän pyritään löytämään ratkaisu muun muassa maahanmuuttoa lisäämällä. (Lutz ym. 2019; BOFIT 2019.) Mahdollisuudet hyvinvoinnin tavoittelulle eivät globaalilla tasolla jakaudu tasaisesti, vaan aiheuttavat osaltaan liikehdintää valtiorajojen yli. Muuttoliikkeiden myötä valtiorajojen sisälle muodostuu ihmisryhmiä, jotka oleskelevat ja työskentelevät ilman valtion takaamia oikeuksia tai turvaa, ollen silti faktisesti osa yhteiskuntaa ja kansantaloutta. Tutkimuksessani toimintamahdollisuuksien yhdenvertainen jakaminen on kuitenkin yksi valtioiden tärkeimmistä rakenteellisista tehtävis- tä. Venäjä on viimeaikaisten arvioiden mukaan yksi maailman viidestä suosituimmasta maahanmuuttokohteesta (UN Population Division 2019). Moskovan kontekstissa toteuttamani etnografinen tutkimus keskittyy toimintamahdollisuuksien tutkimiseen Venäjän pitkäaikaispaperittomien näkökulmasta. Tutkimuskysymykseni on, miten ja miksi valta ohjailee paperittomien toimintamahdollisuuksia.

Kansainvälisesti paperittomuutta on tutkittu yhä enenevässä määrin muun muassa Suomessa, Euroopassa ja Yhdysvalloissa. Tutkimustietoa ilmiöstä globaalilla tasolla, muun muassa ihmisoikeusnäkökulmasta tarkastellen, löytyy jo hyvin (mm. Gonzales 2011; Kara H. 2016; Kara S. 2017; Kubal 
2020). Venäjällä elämä ilman oleskeluun, terveydenhuoltoon ja työntekoon oikeuttavia asiakirjoja on ollut arkea miljoonille Neuvostoliiton hajoamisen jälkeen. Alue on tästäkin syystä erinomainen ympäristö paperittomuusilmiön laajempaa tutkimista ajatellen. Tutkimustietoa harmaan talouden ja työperäisen maahanmuuton suhteesta Venäjän kontekstissa löytyy myös jo kohtalaisesti (mm. Heusala \& Aitamurto 2016; Schenk 2018; Cordell 2019). Tutkimukseni pureutuu erityisesti paperittoman omaan kokemukseen yhteiskuntavallan ylläpitämästä toimintamahdollisuuksien ohjailusta. Tutkimukseen osallistuneet ovat alun perin saapuneet Moskovaan Kaukasuksen alueelta ja Keski-Aasiasta. Jokainen heistä on kokenut pitkäaikaisen, vähintään kymmenen vuotta kestäneen paperittomuuden Moskovassa elämänsä aikana. Osallistuneista (15) kahdeksalla on nykyään Venäjän kansalaisuus. Etnografinen aineisto on kerätty vuosina 2017-2020.

Paperittomuutta on kutsuttu nykyajan orjuudeksi (mm. Noll 2010; Kara 2017). Harmaa talous hyötyy halvasta työvoimasta ja vääristää palkkakilpailua. Paperiton toimii paikallisen talouskasvun ja kansainvälisen valtataistelun helposti hiljennettävänä ja liikuteltavana pelinappulana. Teoreettisena viitekehyksenä tutkimuksessani toimivat Steven Lukesin vallan kolme ulottuvuutta (1974; 2005) ja Martha Nussbaumin teoria toimintamahdollisuuksista (2011). Tutkimuksessani tarkastelen kriittisesti yhteiskunnan valtarakenteita, joissa valtaeliitti hyötyy paperittomien toimintamahdollisuuksien ohjailusta sekä ihmisoikeuksien toteutumattomuudesta.
Tutkimukseni rakentuu niin, että ensin avaan tutkimuksen viitekehyksen, joka muodostuu valtateorian ja toimintamahdollisuuksien suhteesta sekä tämän vaikutuksesta paperittomien toimintamahdollisuuksiin ihmisoikeuskysymystä unohtamatta. Tämän jälkeen siirryn tutkimusaineistoon, jonka kautta tutkimus etenee analyysiin sekä johtopäätöksiin.

\section{VALLAN INTRESSIT TOIMIJUUDEN MAHDOLLISTAJANA SEKÄ RAJOITTAJANA}

Tutkimukseni lähtee liikkeelle toimintamahdollisuuksien ohjailusta osana yhteiskunnan vallankäyttöä. Teoreettisena viitekehyksenä vallalle toimii Steven Lukesin valtateoria (1974; 2005). Valtateorian ensimmäinen ulottuvuus on näkyvää päätöksentekovaltaa (Lukes 2005, 29). Tutkimukseni kontekstissa tämä tarkoittaa paperittoman toimintamahdollisuuksien näkyvää rajoittamista. Karkotuksen uhka sekä sakot toimivat kannustimena valita vallan intressejä palveleva toimijuus. Rangaistukset toteutetaan niiden palvellessa vallan taloudellisia ja poliittisia intressejä. Mahdollisuuksia näkyvälle vastarinnalle ei paperittomalla karkotusuhan vuoksi ole. Ensimmäinen ja näkyvä vallan ulottuvuus erottaa paperittoman täten valtaväestöstä. Vallan toinen ulottuvuus ilmenee tutkimuksessani yhteiskunnallisten päätösten tekemättä jättämisenä, päätösten ristiriitaisuuksina ja raskaana byrokratiana, jotka lisäävät epävirallisten verkostojen sekä vaihtoehtoisten toimintamahdollisuuksien tarvetta ja kehittymistä. Tätä käsittelen luvussa Blat-verkosto ja toimintamahdollisuuden ostaminen. 
Vallan kolmas ulottuvuus saa vallankohteen kuuliaiseksi ilman näkyvää konfliktia (Lukes 2005, 29). Poliittisten puolueiden ajamat intressit vaikuttavat lainsäädännön lisäksi valtaväestön yleiseen suhtautumiseen maahanmuuttajia kohtaan (mm. Abashin 2016). Vallan kohteena ovat tutkimuksessani niin paperittomat kuin valtaväestö, jonka asenteita ja suhtautumista paperittomiin hyödynnetään poliittisessa mielipidevaikuttamisessa. Poliittisen vaikutustyön osalta tutkimukseni myötäilee Peter Kiviston havaintoja median, oikeistopuolueen sekä vanhoillisen kirkon roolista autoritäärisen vallan nousussa Yhdysvalloissa. Kivisto toteaa ilmiön ajankohtaisuuden Atlantin molemmin puolin. (Kivisto 2016, 4.) Kuten Yhdysvalloissa, myös Venäjällä paperittoman toimintamahdollisuudet ja ylläpidetyt mielikuvat paperittomista ovat vallan intressien työkaluja.

Taloudellinen ahdinko kasvattaa riippuvaisuutta työperäisestä maastamuutosta ja paperittomien kotiin lähettämistä tuloista. Arvioiden mukaan vuonna 2018 IVY-maihin lähetetyt rahasummat vastasivat 14 miljardia Yhdysvaltain dollaria (Aleshkovskii ym. 2019, 199). Tarve ohjailee paperitonta toimimaan harmaan talouden ehdoilla tilanteen kiristymisestä huolimatta. $\mathrm{Pa}$ perittoman rinnastaminen rikolliseksi siirtää kansalaisen katseen oman yhteiskunnan eriarvoistavista rakenteista sekä tilanteen taloudellisista hyötyjistä kohti "vierasta", "toista" ja "ulkopuolista". Huomion arvoista on, että maahanmuuttajien osuus Venäjän bruttokansantuotteesta oli 101 miljardia Yhdysvaltain dollaria vuonna 2017, ja näistä maahanmuuttajista arviolta 60 prosenttia oli paperittomia (Aleshkovskii ym.
2019, 199-206). Lähtökohtana on, että vallan perimmäiset, todelliset intressit näyttäytyvät valtaeliitin taloudellisen ja poliittisen voitontavoittelun maksimoinnissa. Steven Lukesin vallan kolme ulottuvuutta ilmenevät paperittomien arjessa yhtäaikaisesti niiden näkyvien sekä näkymättömien mahdollisuuksien puitteissa, jotka paperittoman toiminnalle on suotu.

\section{TOIMINTAMAHDOLlisUUdeT IHMISOIKEUSKYSYMYKSENÄ}

Ihmisoikeusrikkomukset hankaloittavat erityisesti haavoittuvassa asemassa elävien elämää (mm. Human Rights Watch, World Report 2020). Tutkimuskenttänä Venäjä on ihmisoikeuksien näkökulmasta ristiriitainen: suhde YK:n ihmisoikeuksien julistukseen ei ole koskaan ollut yksioikoinen, nimettiin sitten syyksi ihmisoikeuksien perusteiden käsityserot tai globaalit valtataistelut (mm. Patenaude 2012). Ihmisoikeudet on koettu usein LänsiEuroopan valistuskauden tuotteiksi (Ife 2001, 1-2). Itä-länsi -vastakkainasettelu ei ole kuitenkaan estänyt Venäjää ratifioimasta useita YK:n ihmisoikeussopimuksista (UN Human Rights, Ratification Status for Russian Federation).

Tutkimuksessani yksilön oikeus määritellä tarpeensa, ja toimensa näiden tyydyttämiseksi on ihmisoikeuskysymys (Ife 2001, 79). Paperittomien toimintamahdollisuus suhteessa valtaväestöön ymmärretään yhdenvertaisuuskysymyksenä. Martha Nussbaum alleviivaa ihmisen tarpeen kehittyä ja kasvaa ihmisenä, hyödyntää potentiaalinsa ja muokata elämäänsä vastavuoroisesti muiden ihmisten kanssa. 
Tämä korostaa sekä yksilön omien ihmisoikeuksien että yksilöiden välisten riippuvaisuuksien merkitystä. Yksilölle suodut toimintamahdollisuudet kunnioittavat yhteisön moninaisuutta. Kenenkään ei kuulu olla toisen henkilön tai yhteisön valitsema hyödyke tarpeiden täyttämistä varten. (Nussbaum 2000c, 71-73.) Paperittomien toimintamahdollisuuksia ei tule rajoittaa uuden isäntämaan poliittisen valtataistelun ja talouskasvun hyväksi.

Ajatus tarpeiden vuorovaikutteisuudesta, sekä erilaisten, ei ainoastaan taloudellisten köyhyyksien olemassaolosta, on tutkimuksessani läsnä (Schultz \& Tapio 2011, 8). Esimerkiksi paperittoman kohdalla toimijuus perustuu rajoitettujen toimintamahdollisuuksien välillä valitsemiseen. Jokainen valinta johtaa omanlaiseen köyhyyteen. Rajoitetut toimintamahdollisuudet lähtömaassa ohjaavat henkilöitä paperittomiksi ulkomaille. Paperittomuus aiheuttaa uusia toimintamahdollisuuksien rajoituksia, joita harmaa talous pystyy hyödyntämään.Yksilöiden hyvät toimintamahdollisuudet ovat moninaisen yhteiskunnan tulevaisuus ja rikkaus. Toimintamahdollisuudet turvaavat ihmisarvon toteutumisen ja mahdollisuuden kukoistukseen paremmin kuin pelkkien taloudellisten hyödykkeiden tasavertainen jako (Johnson 2013, 7071). Perimmäinen ja koko yhteiskuntaa koskettava köyhyys on ihmisoikeuksien toteutumattomuus.

Kieltämällä oikeudet viralliseen toimintaan osana yhteiskuntaa valtio poistaa ainoastaan viralliset velvoitteet. Hyvinvointiaan tavoitellessaan paperiton on silti osa yhteiskuntaa. Laittomaksi nimeäminen tai ulkomaalaisuudella ja kulttuurisilla tekijöillä selitetty eriarvoisuus ovat keinoja poliittiselle vallankäytölle ja tältä osin niitä voi jäsentää vallan kolmannen ulottuvuuden käsitteen avulla (Lukes 2005, 29). Martha Nussbaum on tutkinut naisten asemaa ja toimintamahdollisuuksia (2000a, b, c), mutta sama ilmiö toistuu myös suhteessa paperittomiin. Maailmasta on vaikea löytää väestöryhmää, joka ei olisi pitänyt toiseksi tai ulkopuoliseksi nimeämänsä yksilön tai ryhmän rajoitettuja toimintamahdollisuuksia perusteltuina, esimerkiksi kulttuurisyihin vedoten. Steven Lukesin valtateoria (2005) ja Martha Nussbaumin käsitys toimivallasta (2011) soveltuvat tilanteisiin, joissa ihmisen alisteinen asema mielletään synnynnäiseksi tekijäksi tai omaksi valinnaksi. Alisteisesta asemasta käsin ei aina ole mahdollista nähdä ulospääsyä vallitsevasta tilanteesta. Tilanteen luonnollisena pitäminen koskettaa sekä valtaväestöä että alisteista väestönosaa. Tilanteen ymmärtäminen edellyttää vallan perimmäisten intressien tarkastelua useammasta eri näkökulmasta.

Elämään mahtuu syntymän, kasvun ja kuoleman lisäksi myös muut sen mukanaan tuomat haasteet, jotka koskettavat myös pitkäaikaispaperitonta (Honkasalo, Ketokivi \& Leppo 2014, 371). Huomionarvoista paperittomien kohdalla on kuitenkin se, että tarpeiden ratkaisemiseksi tarjotut mahdollisuudet, tarpeiden tyydyttäjät, poikkeavat valtaväestölle tarjolla olevista vaihtoehdoista. Ratkaisut ovat usein lyhytaikaisia eikä niiden jatkuvuuteen voi luottaa. Manfred Max-Neefin mukaan ihmisen perustarpeet ovat yhteiset jokaiselle muuttuen hitaasti evoluutiomme mukaan. Tarpeiden sijaan huomio 
kannattaa kiinnittää talouden intressejä palveleviin tarpeiden tyydyttäjiin, jotka vaihtuvat nopeammin, riippuen taloudellisista, sosiaalisista ja poliittisista tekijöistä. (1992, 207-209.)

Tutkimuskysymykseni oli, miten ja miksi valta ohjailee paperittomien toimintamahdollisuuksia. Paperittomille suotujen toimintamahdollisuuksien tutkiminen auttaa havaitsemaan ne tahot, jotka loppukädessä pyrkivät hyötymään paperittomuudesta sekä sen ohjailusta. Martha Nussbaumin toimintamahdollisuuksien teoria (2011) vahvistaa täten kytköksen Steven Lukesin teoriaan vallan ulottuvuuksista sekä sen perimmäisistä intresseistä $(1974 ; 2005)$.

\section{TUTKIMUSAINEISTO, MENETELMÄT JA TUTKIMUKSEN EETTISYYS}

Tutkimuksessani etnografia on metodologiana määritellyt niin kenttätyötä, aineiston kuvausta kuin sen analyysiä (Gobo 2008). Etnografiset haastattelut, havainnointi sekä vuorovaikutus tutkimukseen osallistuneiden kanssa ovat vaikuttaneet tutkimuksen etenemiseen sekä sen lopputuloksiin. Etnografia ilmenee tutkimuksessani myös paperittomuuden kontekstoimisena kohderyhmäni elämänkulun ja yhteiskunnan valtajärjestelmän suomien toimintamahdollisuuksien näkökulmista. (Hämeenaho \& Koskinen-Koivisto 2018, 9-10.) Paperittoman kokemusmaailman kautta tutkimukseni tekee näkyväksi yhteiskunnan valtarakenteiden vaikutukset pitkäaikaispaperittoman toimintamahdollisuuksiin.

Etnografinen tutkimus alkoi Moskovassa joulukuussa 2017 yhdeksän tut- kimukseen osallistuneen kanssa, jotka tavoitin kohderyhmään kuuluvan tuttavani avulla. Tämän jälkeen kohderyhmän edustajat tutustuttivat minut myös muihin henkilöihin, jotka olivat kiinnostuneita osallistumaan tutkimukseen. Ensimmäisen kenttämatkani osallistujat olivat kaikki Georgian mingreleitä, jotka olivat paenneet sotaa Abhasiasta Moskovaan 90-luvun aikana. Toisen kenttämatkan aikana tammikuussa 2020 tutkimukseen osallistui kuusi muualta Kaukasuksen alueelta ja Keski-Aasiasta Moskovaan muuttanutta paperitonta. Heistä suurin osa oli saapunut maahan työn tai vanhempiensa perässä. Yhtä osallistujaa lukuun ottamatta kaikki elivät perheensä kanssa. Kriteereinä osallistumiselle oli yli kymmenen vuotta kestänyt paperittomuus elämän aikana. Yhteensä tutkimukseen osallistui 15 eri ikäistä naista sekä miestä.

Paperittomuus viittaa tutkimuksessani oikeudellishallinnolliseen asemaan yhteiskunnassa ilman oleskeluun, työntekoon, opiskeluun tai alueellisiin sosiaali- ja terveyspalveluihin oikeuttavia asiakirjoja. Yksi osallistujista oli ollut pakolainen sekä paperiton kaksikymmentä vuotta, mutta Moskovassa vasta viikon. Hänen työnhakunsa seuraaminen lisäsi ymmärrystä harmaan talouden ja vallan välisen synteesin vaikutuksista paperittoman vaihtoehtoihin. Toinen pitkäaikaisen paperittomuuden kokeneista osallistujista (nykyään Venäjän kansalainen) kertoi työstään työpatentteja myöntävän maahanmuuttodirektoraatin viranhaltijana, selventäen virallisen ja epävirallisen toimintamahdollisuuden välisen harmaan alueen arkipäiväisyyttä vallankäytön näkökulmasta. 
Etnografisen haastattelun lisäksi havainnointi sekä keskustelut havainnointien pohjalta ovat tutkimuksessani keskeisiä. Kohderyhmäni edustajista suurin osa asui kaukana keskustasta, kuluttaen pelkästään työmatkoihin tunteja päivittäin. Käytin tämän tilaisuuden hyväkseni ja vietin heidän kanssaan aikaa varhaisesta aamusta aamuyöhön, niin kotona, arkisilla asioilla, kuin töissä ja perhetapaamisissa. Istuimme metroissa ja autoissa, liikenneruuhkissa, olohuoneissa ja keittiöissä.

Arjessa havainnointi keskustelun lomassa rikastutti toimintamahdollisuuksien ohjailun ilmenemisen ja merkityksen ymmärtämistä hyvin konkreettisella tasolla. Moskovassa vietin keskimäärin yhden kokonaisen päivän jokaisen tutkimukseen osallistuneen kanssa. Tutkimuskenttä on muodostunut Moskovassa kasvokkain tapahtuvasta luottamuksen rakentamisesta, etnografisista haastatteluista ja kenttätyöstä niin paikan päällä kuin etänä.

Perimmäisenä tutkimuskohteena on kohderyhmäni kokema todellisuus toimintamahdollisuuksien toteutumisesta yhteiskunnan valtarakenteiden sekä vastuiden ja velvollisuuksien suomassa kontekstissa. Toimintamahdollisuuksiin liittyvät havainnot määrittivät suurilta osin tutkimuksessa käytetyn, toimijuutta sekä toimijuuden mahdollisuuksia käsittelevän aineiston valikoitumisen. Hyödynnän tässä tutkimuksessa jokaisen osallistujan kokemuksia.

Yhteistyö kentän kanssa on jatkunut koko analyysi- sekä kirjoitusvaiheen ajan. Nauhoitin etnografisia haastatteluita eniten ensimmäisellä kenttämatkallani. Käytäntö osoittautui kuitenkin haastavaksi liikkuvassa arjessa. Paperilehtiö sekä välillä kännykän muistilehtiöön kirjatut huomiot muistuttivat osallistujia roolistani tutkijana muuttamatta tunnelmaa yhtä vahvasti, pysäyttämättä ympärillä pyörivää arkea ja sen kanssakäymisiä. Lehtiöön kertyi haastatteluiden lisäksi piirustuksia ja elämänvaiheita kuvailevia kaaria niin itseltäni kuin osallistuneiltakin, tietoa tilassa olevista muista ihmisistä, sanattomasta kommunikoinnista ja reaktioista. Etäyhteys kentälle on jatkunut kenttävaiheiden jälkeen keskeytymättömänä. Yhteydenpito on tapahtunut Whatsappin sekä Telegrammin kautta viesteinä, puheluina tai videopuheluina. Tallentuneet ääniviestit, tekstiviestit sekä videot olen deletoinut turvallisuussyistä tasaisin väliajoin.

Suurella osalla tutkimukseeni osallistuneista on ammatti- tai korkeakoulututkinto. Koen tämän vaikuttaneen yhteistyöhön. Tutkimukseen osallistuneet suhtautuivat tutkimukseen avoimesti ja mielenkiinnolla, ajatuksiaan jakaen. Positioin itseni tutkijana, mutta tutkimus on ehdottomasti yhteistyön tulosta, tarkoituksena tuoda paperittomuusilmiön rakenteelliset tekijät laajempaan tietoisuuteen kohderyhmän näkökulmasta (Marttila 2018). Suurin osa Moskovaan tulevista uusista maahanmuuttajista tulee tällä hetkellä Kirgisiasta, Tadzhikistanista, Moldovasta, Uzbekistanista tai Ukrainasta (Aleshkovskij ym. 2019, 198). Työpatentteja myöntävä viranhaltija korosti suuren osan saapuvan ilman tunnistettavaa korkeakoulututkintoa. Koulutustaustasta huolimatta paperittoman toimintamahdollisuudet yhteiskunnassa ovat valtaväestön toimintamahdollisuuksiin verrattuna rajoitetut ja ohjautuminen matalapalkkaisiin teh- 
täviin enemmän kuin todennäköistä. Venäjän ristiriitainen rooli useamman rajavaltionsa kanssa aiheuttaa sen, että rajavaltioiden talous on riippuvainen Venäjästä, joka itse taas tarvitsee alueelleen halpaa työvoimaa.

Eettinen valppaus (Jäppinen 2015, 8085) on tutkimuksessani ollut tärkeätä niin kentällä Moskovassa kuin analyysi- ja kirjoitusvaiheessa sekä etäyhteydellä toimiessani. Tämä tarkoittaa ensisijaisesti valmiutta tiedon luotettavuuden ja oman tulkintani jatkuvaan arvioimiseen sekä anonymiteettisuojan kunnioittamiseen. Osallistuneet ovat olleet valmiita ilmoittamaan alkuperäisen kotimaansa, sukupuolensa sekä nimensä. Anonymiteettisuojan mainitseminen on aiheuttanut olankohautuksia ja leveää hymyä. Moni tutkimukseen osallistuneista olisi halunnut nimensä näkyviin tutkimukseen, vaikka olivat itse kyseisellä hetkellä paperittomia tai olleet vuosikausia paperittomina. Yksi yhä edelleen paperittomana elävä moskovalainen tiivisti todellisuuden minulle toteamalla: "Ei tässä mitään uutta ole, kaikki tästä tietävät, minäkään en ole mikään salaisuus". Tunnistetiedot on kuitenkin poistettu osallistuneiden oman sekä heidän perheenjäsentensä anonymiteetin turvaamiseksi. Osallistujat ovat ilmaisseet ymmärtävänsä tutkimuksen tavoitteet ja osallistumisen vapaaehtoisuuden.

Analyysissa fokusoin huomion toimijuuteen vallan suomien toimintamahdollisuuksien ja tarpeiden ristitulessa. Aineisto on ryhmitelty Steven Lukesin valtateorian mukaisten ulottuvuuksien ilmenemisen mukaan $(1974 ; 2005)$. Tämän jälkeen olen analysoinut vallan suomia paperittomien toiminta- mahdollisuuksia hyödyntäen Martha Nussbaumin toimintamahdollisuuksien teoriaa (2011). Steven Lukesin sekä Martha Nussbaumin teorioiden hyödyntäminen analyysissä on mahdollistanut vallan perimmäisten intressien ja vallankäytön paikantamisen. Steven Lukes on valtateoriassa keskittynyt vallankäytön eri ulottuvuuksiin, ei niinkään valtarakenteisiin. Valtarakennelmat paperittomuusilmiön takana paljastuvat soveltamalla Lukesin teoriaa Martha Nussbaumin toimintamahdollisuuksien teoriaan. Etsimällä vastausta kysymykseen, miten ja miksi valtaa käytetään toimintamahdollisuuksien ohjailemiseen, pääsemme samalla selville siitä, mitä intressejä valtarakennelmat yhteiskunnassa ajavat.

Analyysissa keskityn valta- sekä toimintamahdollisuuksien teorioiden näkökulmasta venäläisten blat-verkostojen merkitykseen, perheen rooliin toimintamahdollisuuksien valinnassa, elämänkaaren eri vaiheisiin sekä paperittomien yhteiskunnalle tuoman taloudellisen merkityksen vaikutuksiin toimintamahdollisuuksien ohjailussa.

\section{BLAT-Verkostot Ja}

TOIMINTAMAHDOLLISUUDEN OSTAMINEN

Blat-ilmiön ymmärtäminen on avainasemassa tutkiessamme toimijuutta venäläisen yhteiskunnan kontekstissa. Virallisen yhteiskuntajärjestelmän rinnalla kulkee vaihtoehtoinen blat-järjestelmä, joka tarkoittaa ensisijaisesti sosiaalista verkostoa ja kontakteja, jotka mahdollistavat yksilön toimijuuden. Blat oli tuttu käytäntö Neuvostoliiton aikana perustarpeiden kattamiseksi. Tutkimuksessani blat-järjestelmä näyttäytyy 
erityisesti niissä tilanteissa, joissa byrokratia, päätöksenteko, tai päätöksien toteuttaminen ja niiden mukaan toimiminen on tehty niin haastavaksi, että ihminen turvautuu kontakteihinsa ja vaihtoehtoisiin toimintamahdollisuuksiin muun muassa ruuan, työpaikan ja asunnon järjestymiseksi:

\section{Me emme osanneet varastaa niin nälkäisinä nukuttiin. Tytär syntyi, kun olimme jo saa- neet kauppamme avattua. Paikalliselle mak- soimme siitä, että se oli hänen nimissään, hän tarjosi tätä itse. Laitoimme kauppam- me hänen nimiinsä, me maksoimme siitä. Ja sitten vuonna 97 syntyi tytär. Maksettiin kätilölle. (Yli kymmenen vuotta pape- rittomana Moskovassa perheensä kanssa elänyt)}

Kohderyhmäni tapauksessa verkostot sekä lahjonta kulkivat rinnatusten arjessa synnytysosastolta hautausmaalle. Verkostot paikallisten kanssa ovat maahanmuuttajilla usein heikommat ja siksi toimintamahdollisuudet perustuvat pitkälti kontakteihin, joiden kautta tieto maksua vastaanottavista tahoista liikkuu.

Hyvin moni epävirallinen toimintamalli on julkinen salaisuus ja kiinteä maksu etukäteen sovittu (Kalm-Akubardia 2019, 13). Alena Ledenevan tutkimuksen mukaan epävirallisia toimintamalleja ja lakien kiertämistä ilmenee eritoten sellaisissa yhteiskunnissa, joissa ylisäännöstely sekä määräyksien huono täytäntöönpano ilmenevät rinnakkain (Ledeneva 2011, 722). Blat voidaan nähdä toimintamahdollisuuden tarjoavana verkostona siellä missä muuten toimintamahdollisuuksia olisi hyvin hankala saavuttaa. Paperittomien toimintamahdollisuudet perustuvat rakenteessa ilmeneviin ja alati kehittyviin vaihtoehtoisiin toimintamalleihin, joiden turvin uusikin paperiton löytää tiensä yhteiskuntaan.

Blat koskee jokaista yhteiskunnan toimijaa. Virallisen ja epävirallisen järjestelmän rajaviivaa on vaikea määritellä. Yhdeltä luukulta voi saada erilaisia ratkaisuja, jotka keskustelevat keskenään ja palvelevat lopulta samaa valtaa. Ihmiset hyötyvät blatista ja blat virallisen valtiojärjestelmän asettamista haasteista, jotka ylläpitävät sen kannattavuutta. Opiskelupaikan, terveyspalveluiden ja työpaikan saamisessa avustaminen ovat avaimia valtaan, sillä moni on valmis tekemään suuriakin uhrauksia näiden eteen. Steven Lukesin valtateorian $(1974 ; 2005)$ toinen ulottuvuus näkyi kentällä muun muassa päätöksien ristiriitaisuutena ja toimeenpanon harmaina alueina sekä päätöksien tekemättä jättämisenä. Nämä kaikki edistävät blat-vaihtoehdon kannattavuutta sekä harmaan talouden kehittymistä.

Toimijuuden mahdollistaminen erilaisin ehdoin on Moskovassa arkipäiväistä. Avoin keskustelu toimintamahdollisuuksien harmaasta alueesta ei tuota ongelmia. Huomionarvoista toki on, että kohderyhmäni koostuu entisen Neuvostoliiton kansalaisista, joten järjestelmä oli yhteinen jo ennen paperittomuutta. Muutama tutkimukseen osallistuneista jätti tietoisesti lauseita kesken kulmien alta hymyillen tai päätä pudistellen, näyttäen että pystyin itse päättelemään miten järjestelmä todellisuudessa toimi. Loput aloittivat itse keskustelun suhteiden sekä rahan merkityksestä toimijuuden mahdollistajina. 


\section{Perheen merkitys}

\section{TOIMINTAMAHDOLLISUUKSIEN VALINNASSA}

Toimintamahdollisuuksien ohjailu koskettaa sekä paperitonta itseään että hänen perhettään, sillä toiminnan toteutumisen taustalla on mitä useimmin tarve maksaa oman ja lähimmäisen paperittomuuden aiheuttamista lisäkustannuksista. Samaan aikaan mahdollisuudet hyvätuloiseen työhön ilman työlupaa ovat heikot. Yhden pienituloisen ihmisen palkka ei riitä turvaamaan edes peruskuluja, ja tämä lisää perheen merkitystä selviytymisessä. Paperittomana kasvanut henkilö tietää ne uhraukset, jotka hänen sukulaisensa ovat mahdollisesti tehneet hänen koulutuksensa eteen. Aikuistuessaan nuoren tulee huolehtia myös nuorempien sisarusten koulumaksuista sekä kotimaahan jääneiden sukulaisten tarpeista. Toimintaa ohjailevat yhteiskunnan rakenteiden rinnalla oman verkoston tarpeet.

Sodan jälkeiset vuodet Moskovassa, muistan, oli vaikeata. Ei normaalia ruokaa, vettä, asuntoa. Rakastan tanssia. Tanssin 18 vuotta, kolme kertaa viikossa aina kaksi tuntia. Sulkeuduin tanssin maailmaan. Se pelasti minut. Tanssilla ei saa rahaa, minun oli valittava työ, josta sain palkkaa. Asun vieläkin perheen kanssa, kaikki on yhteistä, palkka, auto, kaikki. Siskoni opiskelee lääketieteellisessä. Yksin olisin tanssilla elänyt mutta en perheellisenä. Työtäni en tee sydämellä vaan järjellä, se on hyvä työ, voin kehittyä. Tiedän että vanhempani hylkäsivät omat unelmansa meidän lasten takia. Nyt kun on stabiilimpaa, jos saan omia lapsia, toivon että lapset löytävät oman polkunsa, ja pystyvät siten toteuttamaan itseään. $N y t$ olen ymmärtänyt, että sydäntä pitää kuunnella myös työn suhteen. Paperiton on "tyhjä tila", et voi puuttua edes perusasioihin, sinulla ei ole oikeutta. Valta on rahaa. Jos on rahaa, niin kaikki onnistuu. Paperiton maksaa vain kaikesta vähän enemmän (Paperittomana Moskovassa lapsuuden ja varhaisnuoruuden)

Kohtaamani pitkäaikaispaperiton vertasi omaa elämäänsä paperittomana "tyhjäksi tilaksi", jossa omat osaamiset ja intohimot jäivät työelämän osalta hyödyntämättä. Realistiset mahdollisuudet omien osaamisten ja toiveiden kuuntelemiseen ovat jääneet toteutumatta niin paperittomuuden aikana kuin sen mahdollisesti päätyttyä. Institutionaaliset tekijät sekä velvollisuudet lähimmäisiä kohtaan vaikuttivat pitkäaikaispaperittoman kokemiin toimintamahdollisuuksiin ja koettuun hyvinvointiin.

Martha Nussbaum ottaa toimintamahdollisuuksien teoriassaan huomioon yksilön osaamisen lisäksi mahdollisuuden toimia yhteiskunnassa poliittisella, sosiaalisella sekä taloudellisella tasolla (Combined Capabilities Nussbaum 2011, 20-21). Tutkimukseeni osallistuneet ovat kouluttautuneita. Täyttymystä kodin ulkopuolelta ei kuitenkaan ole voinut hakea autonomisena kansalaisena. Vaikka kouluttautuminen paperittomana olisikin onnistunut, on koulutusta vastaavan työn saaminen osoittautunut mahdottomuudeksi. Lisäksi omien ja lähimmäisten perustarpeiden tyydyttäminen läheisten haastavassa elämäntilanteessa on muodostunut esteeksi oman itsensä vapaalle kehittämiselle. Osalla oli perheessä paperittomuuden rinnalla terveydellisiä huolia, vanhenevat vanhemmat, raskauksia sekä kuolemia, jotka aiheuttivat pitkä- 
aikaisia ja mittavia taloudellisia kulueriä koko läheisten verkostolle.

Olin töissä ravintolassa, kaupassa, kaikkialla. Autoin perhettä, lähetin rahaa kotiin. Olen katkera, että en päässyt yliopistoon päättämään opintojani. Ei onnistunut. (Odottaa Venäjän kansalaisuutta, yli 20 vuotta paperittomana)

Omista unelmista puhuminen ohitettiin keskusteluissa usein olankohautuksella. Kohteliaasti hymyillen siirryttiin puhumaan perheen merkityksestä, omien vanhempien uhrauksista, ja omien tulevien tai jo syntyneiden lasten paremmista valinnanvapauksista. Näin on toki myös monen valtaväestöön kuuluvan kohdalla. Huomionarvoista on kuitenkin se, että suurin osa tutkimukseen osallistuneista asuu alueella vakituisesti, mutta toimii silti paikalliseen tasoon verrattuna matalapalkkaisissa tehtävissä ilman mahdollisuutta yhteiskunnan suojaan tai terveyspalveluihin.Vaihtoehdot ovat siis rajoitetummat.

Keskinäinen tuki on auttanut ja velvoittanut. Tältä osin pitkäaikaispaperittoman on löydettävä mahdollisuudet itsensä toteuttamiselle suhteissaan lähimmäisiinsä. Itsensä toteuttaminen tapahtuu pienemmässä sosiaalisessa piirissä, niiden ehtojen puitteissa, jotka yhteiskunta suo omien sekä lähimmäisten peruselinehtojen täyttymiseksi. Paperiton nuori on kasvanut todellisuuteen, jossa hänen on aikuisena kyettävä auttamaan laajaakin lähiverkostoa, myös rajojen yli. Vallan suomien vaihtoehtojen puitteissa paperiton valitsee myös lähimmäistensä takia sen vaihtoehdon, joka mahdollisimman riskittömänä on tarjolla.
Toimintamahdollisuuksien rajoittaminen ilmenee yhteiskunnassa suorana ja välillisenä. Päiväkotipaikan saaminen tukee ulkomaalaisen lapsen kielellistä kehittymistä, verkostoitumista ja koulun aloitusta tasavertaisesti muiden lasten kanssa. Päiväkoti mahdollistaa vanhempien toiminnan kodin ulkopuolella. Moskovassa on tällä hetkellä kuitenkin suuria vaikeuksia saada lapselle päiväkotipaikkaa, erityisesti tämä koskee henkilöitä ilman Venäjän kansalaisuutta. Paperittomille tilanne on mahdoton ilman vahvoja verkostoja ja maksukykyä. Tästä syystä lapsen hoito kotona ei perustu samanlaisiin valinnanmahdollisuuksiin kuin valtaväestöllä.

Kaukasuslainen perhe käsittää ydinperheen lisäksi myös muut läheisiksi lasketut sukulaiset, joiden määrä on helposti yli kolmekymmentä henkilöä. Seuraavaksi sitovimman verkostonosan muodostavat ystävät, sitten naapurit, ja tämän jälkeen saman kansalaisuuden jakavat henkilöt (Aliyev 2013, 93). Jokaisen perheenjäsenen asema vaikuttaa koko perheeseen isovanhemmista serkkuihin asti, myös rajojen yli. Tästä syystä hyvinvoinnin tavoittelu ei ole yksilön oma asia tai valinta.
Perheen takia en luovuttanut, oman perheen perustamisen takia en luovuttanut. Nyt tar- vitsee huolehtia, että oma lapsi pääsee ja- loilleen. Sukulaiset ja heidän tukensa ja tu- kemisensa kompensoi. Perheen kautta sain kärsimykseni ja uhraamani asiat takaisin Jumalalta kaksinkertaisena. (Moskovas- sa paperittomana yli kaksikymmentä vuotta)

Muiden puolesta uhrautuminen nähtiin hyveenä ja tästä syystä suuremmatkin henkilökohtaiset luopumiset näyt- 
tivät olevan helpommin hyväksyttävissä ja sanoitettavissa. Muille antaminen on ollut työtä yhteisen turvan eteen.

\section{Pitkäaikaispaperittoman TOIMINTAMAHDOLLISUUDET ELÄMÄNKAAREN HAASTEISSA}

Ilman ajan merkityksen tiedostamista toimijuutta ei voida kunnolla analysoida. Yhteiskunnan rakenteet sekä vaihtelevasti tarjolla olevat vaihtoehdot vaikuttavat toimijuuteen. Tästä syystä toimijuutta ei pysty tavoittamaan yksinomaan toimijaa, tässä tilanteessa paperitonta, tutkimalla. Mustafa Emirbayer ja Ann Mische (1998, 970-974) ovat määritelleet toimijuuden aikaan ja muuttuvaan ympäristöönsä sitoutuneena: toimijuus vaikuttaa interaktiivisesti rakenteisiin joko niitä toistamalla tai muuttamalla. Pitkäaikaista sitoutumista vaativan toiminnan järjestäminen (esimerkiksi koulutuksen tai kroonisen sairauden hoito) on haastavaa ympäristössä, jossa toimijuus perustuu nopeisiin muutoksiin, paikallisen ja kansainvälisen valtapelin vaihtelevien intressien määrittelemien reunaehtojen noudattamiseen, sekä riippuvaisuuteen omien verkostojen vaihtelevista varoista ja tarpeista. Minkään varaan ei voi laskea. Tämä lisää turvattomuutta ja huonovointisuutta.

Me emme koskaan saaneet tukea mistään, ei ollut Punaista ristiä, kirkkoa tai muuta. Jotkut saivat pakolaisen paperit silloin ihan alussa, juuri kun sota alkoi. He saivat asunnon ja vähän apua. Me tulimme tosi myöhään, silloin kun kotona ei ollut enää mitään ja tääläkään ei ollut enää mitään, ainoastaan kaaos. (Eläkeläinen, paperit- tomana Moskovassa yli kaksikymmentä vuotta)

Yksikään tutkimukseeni osallistuneista ei ollut saanut tukea paperittomuuden vuosina verkostojensa ulkopuolelta. Perheen velkoihin ja menoihin on jotenkin täytynyt kuitenkin varautua. Oma tai perheenjäsenen turvaton asema tekee paperittomasta helpommin vallan alle taivuteltavan. Tämä koskee myös niitä henkilöitä, joille kansalaisuus on jo myönnetty, mutta joilla osa lähipiiristä on yhä paperittomina. Yksilön valinnat vaikuttavat hänen verkostonsa hyvinvointiin myös paperittomuuden päätyttyä. Kykenemättömyys molemminpuoliseen avunantoon verkoston perheiden kesken aiheuttaa silminnähden epämieluisan riittämättömyyden tunteen myös niissä perheissä, joissa oli omia akuutteja kulueriä. Rahaa ja kontakteja tarvitaan häiden sekä hautajaisten lisäksi akuutteihin sairaustapauksiin ja jatkuvana kulueränä lasten mahdollisten päiväkoti- ja koulutuspaikkojen järjestämiseen.

Paperittomuuden pitkittyessä lisäansioita hankkivista ja lapsia hoitavista isovanhemmista on tullut geriatrista hoitoa tarvitsevia vanhuksia. Työikäisten aikuisten tarinoissa vilisevät samanaikaiset huolet lasten tulevaisuudesta sekä omien vanhempien terveydestä. Epävarmuudessa eläminen on vaikuttanut sekä henkiseen että fyysiseen koettuun hyvinvointiin. Pitkäaikaisia hoitoja kustannetaan Moskovassa kalleimpaan turistihintaan. Tutkimukseeni aktiivisesti osallistunut viisikymmentävuotias mies totesi viimeisessä tapaamisessamme, että paperittomana eletyn elämänvaiheen seuraamukset terveydelle jäävät nähtäväksemme. Puoli vuotta tämän 
jälkeen hänen sydämensä petti ja hän menehtyi. Vuosia jatkuneet haasteet olivat läheisten ja omien havaintojeni mukaan vahvasti osasyinä ennenaikaiseen kuolemaan.

Hoitamatta tai väärin hoidetuiksi jääneet krooniset sairaudet kuten diabetes, sydänsairaudet ja masennus ovat itselääkinnän, komplikaatioiden sekä aikaisten kuolemien osalta aiheuttaneet huolta ja suuria kuluja useamman osallistuneen perheessä.

Lääkkeitä täallä löytyy ilman reseptejä kyllä vieläkin, on kiellettyjäkin apteekkeja, mutta niitä ei suljeta, siellä on paljon huumeriippuvaisiakin asiakkaina. Näet tunnin sisään sata narkomaania, kukaan ei sitä toimintaa sulje. Jollain on vaan hyvät suojelijat, hyvä liiketoiminta. (Lääkäri, nykyään Venäjän kansalainen)

Moskova on suurkaupunkina valikoitunut osalle paperittomista kohteeksi, koska se pystyi entisenä Neuvostoliiton pääkaupunkina tarjoamaan parempaa erikoishoitoa verrattaessa pienempiin, konfliktien ja taloudellisten haasteiden runtelemiin kotikaupunkeihin. Yksi perheistä yritti asua entisessä kotimaassaan vuosia sodasta huolimatta. Muutto Moskovaan tapahtui lapsen sodan seurauksena saaman päävamman takia, joka vaati erikoissairaanhoitoa. Moskova on ollut ainut mahdollisuus yrittää saada hoitoa myös erilaisiin pitkäaikaisiin sairauksiin, vaikka tämä ei aina ole tavoittelusta huolimatta täysimääräisenä toteutunutkaan. Erillistä paperittomien klinikkaa Moskovassa ei ole ja itselääkintä on tästäkin syystä yleistä.

Kohderyhmäni terveyteen liittyvät tarpeet on pyritty priorisoimaan koko perheen voimin. Moskovassa paperiton pääsee sairaalahoitoon ainoastaan kiireellisessä tapauksessa kolmeksi päiväksi. Kiireellisiin tapauksiin ei lasketa mukaan esimerkiksi synnytyksiä tai pitkäaikaissairauksia.

Paperittomina syntyneet eivät saa kansalaisuutta, siksi synnytyssairaalat eivät saa niistä rahaa. Yksityisiä synnytyssairaaloita ei ole.Yksityisiä ovat meillä vain pienet erityisklinikat, mutta heti jos on jotain vakavampaa tai synnytyksiin liittyvää ja kallista niin yksityinen ei riitä.Yksityisillä tehdään vain diagnooseja ja pieniä operaatioita, muuten pitää mennä kunnalliseen ja jotenkin saada keskusteltua asia siellä. (Lääkäri, nykyään Venäjän kansalainen)

Hoitoon hakeutuminen sisältää myös tietoisen riskin virkavallan läsnäolosta ja henkilökunnan ilmoitusvelvollisuudesta:

Päivystyksessä näen uzbekistanilaisia ja tadzhikistanilaisia ilman dokumentteja. Heidät on usein hakattu. He eivät halua itse jäädä sairaalaan. Poliisi käy meillä, jos alueella on tapahtunut jotain laitonta, ja meidän on ilmoitettava, keitä meillä on hoidossa. Jos emme sitä tietoa anna niin menetämme lupamme. Meidän pitää antaa nimilistat, jos poliisi niitä pyytää. Paperittomat usein eivät halua huomiota, ja jos heidät on hakattu, niin he kirjoittavat papereihin, etta he ovat itse kaatuneet, vaikka kyllä sen näkee, että ne on hakattu, mutta he kirjoittavat, että heillä ei ole mitään tarvetta haastaa ketään. Sitten me ei poliisille kerrota heistä, saavat olla rauhassa. (Lääkäri, nykyään Venäjän kansalainen)

Virallisella tasolla kaupungin sosiaalipalvelut maksavat paperittoman hautauskulut. Käytännössä, mikäli vaina- 
jalla on perhettä, maksaa perhe kulut kalleimpaan hintaan, jotta paperittomuuteen ei asiakirjoissa takerruttaisi. Vainajat lähetetään mahdollisuuksien mukaan kotimaahan haudattaviksi. Muussa tapauksessa heidät haudataan Venäjälle. Molemmissa tapauksissa paperittomuus aiheuttaa ongelmia.

Omaiseltani katosi matkapuhelin, kun poliisit olivat kotonamme. Tuttavamme asuu naapurustossa. Hän oli ehtinyt meille ja riisunut omaiseltamme korut. Sanoi, että muuten ne viedään. Hänellä oli asiasta aikaisempaa kokemusta. Puhelin oli jäänyt omaiseni taskuun ja poliisit olivat meillä kotona ennen kuin minä saavuin. Se puhelin katosi sieltä taskusta. Minä näin, että se kännykkä oli myöhemmin käytössä Moskovan alueella. Se oli hyvin tuskallista minulle. Suljin sen liittymän, minulla ei ollut mitään keinoa saada sitä puhelinta takaisin. Uskon että he olisivat vieneet meiltä enemmänkin tavaraa, jos olisivat vain ehtineet, mutta saavuin paikalle ajoissa. Olin vain niin sekaisin siinä tilanteessa, että en ehtinyt ihan kaikkea huomata, mutta yksi niistä poliiseista kävi katseellaan läpi meidän koko asunnon. (Kuolleen omaisen tytär, paperittomana koko lapsuuden ja nuoruuden, nykyään Venäjän kansalainen)

Virallisten määräysten lisäksi haasteita riittää myös kentän turvattomuuden kanssa. Paperittoman omaisuutta saattaa kadota eikä näiden menetysten takaisinsaamiseksi ole tukea saatavilla. Tämä koskee niin terveitä, sairastuneita kuin kuolleitakin. Valitusta vallan väärinkäytöksistä, esimerkiksi omaisuuden katoamisista tai väkivallasta, ei kannata tehdä.

\section{Paperittomien}

\section{TALOUDELLINEN MERKITYS JA}

TOIMINTAMAHDOLLISUUKSIEN OHJAILU

Venäjällä asuvat paperittomat muodostavat heterogeenisen ryhmän eri kansalaisuuksien edustajia, joiden toimintamahdollisuuksia ylläpitää, ohjailee ja hyödyntää pitkälle kehittynyt harmaa talous. Paperittomista on muodostunut taloudellisesti merkittävä tulolähde niin kotimaille, kohdemaille kuin siirtolaisuutta ylläpitäville tahoille. Inhimillisen kehityksen indeksin mukaan toimeentuloa tarkasteltaessa tulisi huomioida ulkomailla työskentelevien kotiin lähettämät varat näiden muodostaessa tärkeän siivun kotimaahan jääneiden läheisten toimeentuloa (Gamble 2013, 670). Arvioiden mukaan vuonna 2017 Venäjällä työskentelevien ulkomaalaisten määrä oli yhteensä noin 7,2 miljoonaa henkilöä ja osuus noin 6,4 prosenttia koko Venäjän bruttokansantuotteesta. Näistä arviolta 4,3 miljoonaa henkilöä toimii paperittomina. (Aleshkovskii ym. 2019 198.) Tämä on tuonut lisäansion mahdollisuuden useammalle yhteiskunnan toimijalle.

Maahanmuuttajien kotiin lähettämät rahat ovat vaihtoehtoinen, valtioiden välistä riippuvaisuus- ja valtasuhdetta ruokkiva sosiaaliturvajärjestelmä, jota hyödynnetään paikallisella sekä kansainvälisellä tasolla niin rauhan kuin erimielisyyksien aikana. Venäjän väestömäärän on arvioitu laskevan 7,3 miljoonalla kansalaisella vuoteen 2035 mennessä. Tendenssiä pyritään tasapainottamaan työperäisellä maahanmuutolla. (Ganeeva ym. 2019.) Moskovassa yksinään työlupajärjestelmän monimutkaisuus ja yksilöä rahastava byrokratia ohjaavat osan maahanmuut- 
tajista paperittomiksi matalapalkkaisille aloille, joihin paikallisia työntekijöitä ei riitä. Paperittomuus lisää epävarmuutta, ja juuri tämän vuoksi työn eteen ollaan valmiita tekemään myönnytyksiä palkan ja työehtojen suhteen (mm. Light 2010, 301).

Valtaväestön mielikuvien muokkaaminen on keino saada ääniä samalla kun tuetaan entistä halvemmasta työvoimasta hyötyviä työnantajatahoja. Paperittomille tämä tarkoittaa tasapainottelua valtaväestön mielikuvien, kiristyneiden olosuhteiden ja harmaan talouden tarjoamien työmahdollisuuksien välillä. Mitä suuremmaksi ulkoapäin koettu uhka katutasolla koetaan, sitä helpompaa on autoritäärisen johtamistavan oikeuttaminen. Paperittoman uuden asuinmaan ja alkuperäisen asuinmaan kansainväliset suhteet sekä liiketoiminta kärsivät taloudellisten menetysten lisäksi karkotuksista ja kiristyneistä rajakontrolleista. Valtaväestön hegemoniaa uhkaavina mainostettuja paperittomia rinnastetaan oikeudettomiin sekä rikollisiin. Tämä osaltaan ohjaa heidät vahvemmin harmaan talouden piiriin. Paperittomien työolot sekä alhainen palkkataso lisäävät epätasa-arvoa ja kieroutunutta palkkakilpailua työelämässä (Ivakhnyuk 2009, 52-64).

Maahanmuuton käytännöt ovat viime vuosina muuttuneet, mutta keinot sääntöjen kiertämiselle keksitään silti. Tuoreita tutkimustuloksia löytyy myös muun muassa Yhdysvaltojen sekä Iso-Britannian tilanteista (mm. Kaushal 2019; Bloch \& McKey 2016). Paperittomuus on työnantajaosapuolelle kannattavaa ja sille löydetään tarvittaessa paperittoman näkökulmasta entistä riskialttiimmat keinot toteutua.
Harmaan talouden ja paperittomuuden vastustaminen ilmenevät vallanpitäjien poliittisissa puheissa. Käytännön tasolla valta mahdollistaa ja kehittää paperittomuutta (Bloch \& McKay 2016, 183). Miljoonien ilman työlupaa työskentelevien paperittomien toimintamahdollisuuksien sekä julkisuuskuvan muokkaamisessa on kyse vallan ja varojen tietoisesta jakamisesta (mm. Light 2015; Schenk 2018). Useiden Venäjän naapurimaiden heikko taloudellinen tilanne jatkuu. Tämä tarjoaa runsain mitoin venäjää osaavia työntekijöitä Moskovan harmaan talouden tarpeisiin (Adrienko \& Guriev 2005, 8, 21).

Paperittomien ohjautuminen matalapalkkaisille aloille näyttäytyy vallan ohjailemana. Työpatentti on työlupaan verrattava asiakirja, jota voivat Venäjän sisäministeriön maahanmuuttodirektoraatista ${ }^{1}$ hakea ne henkilöt, jotka eivät tarvitse viisumia ja joiden kotimaa ei kuulu Euraasian tulliliittoon. Muut kuin viisumivapaasti matkustavat kansalaiset hakevat työlupaa, jonka hakuprosessi eroaa työpatentin hakuprosessista. Työpatenttia varten ulkomaalaisen on itse hoidettava virallinen käännös passista, vakuutusmaksut, terveystarkastus (mm. hiv-, ja psykotrooppisten aineiden testi), sekä venäjän kielen, historian ja lainsäädännön koe. Tämän lisäksi työntekijän tulee maksaa kuukausittain (työn maantieteellisen sijainnin mukaan) noin 50-65 euroa kuukaudessa tuloveroon rinnastettavaa maksua. Työpatentti rajaa työntekoalueen sekä työalan. Ilman työpatenttia työskentelystä voi saada sakkoja sekä karkotuspäätöksen. (Migrantmedia 2020.) Työpatenteilla toimitaan useimmiten matalapalkkaisissa tehtävissä, jolloin kuukausittain maksettava summa on 
noin 20 prosenttia kokonaispalkasta ${ }^{2}$. Mitä pienempi palkka, sitä suurempi kuluerä patentin hankkiminen siis on. Kansalaisten tulovero on 13 prosenttia palkasta. Työpatenttikäytäntö on siis verrannollisesti kallis, rajoittava ja aikaa vievä eikä sitä kaikille edes myönnetä. Paikallisen patentteja myöntävän työntekijän käsityksen mukaan noin puolet matalapalkkaisten alojen työntekijöistä työskentelevät juuri tästä syystä ilman lupaa.

Työpatentin kuluerät ja sakkoihin rinnastettavan lahjuksen suuruus mahdollisesta kiinnijäämisestä vastaavat kentällä kuulemani tiedon mukaan toisiaan. Tutkimukseen osallistuneet kertovat, että Ukrainan konfliktin seurauksena ilman työlupaa työskentelevien ukrainalaisten määrä Venäjällä on noussut ja aiheuttanut kilpailua matalapalkkaisista tehtävistä. Kehittynyt harmaa talous ohjaa paperittomat matalapalkkaisiin tehtäviin, joissa kiinnijäämisen riski on pienin. Jotkut uusista maahanmuuttajista pyrkivät hankkimaan työpatentin, mutta hankinta- sekä ylläpitokustannukset muodostuvat ylitsepääsemättömiksi varsinkin niissä työtehtävissä, joissa ei ole kiinteää kuukausipalkkaa. Paperittomuus ja työskentely ilman työpatenttia lisäävät epätasa-arvoista palkkakilpailua työelämässä. (mm. Ivakhnyuk 2009, 52-64.) Matalapalkkaisten alojen työnantajat voivat ostaa itsensä vapaiksi tarkastuksista, joten halvasta työvoimasta hyötyvät työnantajaedustajien lisäksi myös lahjuksia vastaanottavat virkamiehet.

Vallan perimmäiset intressit paljastuvat, kun tarkastelemme paperittomien hyvinvoinnin tavoittelun haasteita ja niistä hyötyviä tahoja Moskovan kontekstissa:
Kaikki hyvinvoinnissa tiivistyy papereiden saamiseen, mutta millä hinnalla? Kilometrien mittaiset jonot, fiktiiviset avioliitot, tuhansia euroja rahaa palaa. Paperittomuus on Moskovalle kannattavaa. Sekä luvalliset että luvattomat maahanmunttajat tuovat rahaa. Ei tarvitse maksaa heidän [paperittomien] terveydenhuollostaan, asunnostaan, mistään. He tekevät ne työt, joita muut eivät tee. Maahanmuuttajat ovat halpaa työvoimaa, joka vielä maksaa työpatentista, että pääsisi sitä halpaa työtä tekemään. Tai sitten eivät hanki sitä lupaa vaan toimivat paperittomina ja maksavat lupansa lahjuksina sinne tänne. Tämä on heille [maahanmuuttajille] silti parempi vaihtoehto kuin olla kotona ilman töitä. (Nuoruutensa paperittomana Moskovassa elänyt, nykyään Venäjän kansalainen)

Paperiton turvaa olemassaolonsa yhteiskunnassa lopulta rahalla. Tämä tarkoittaa sitä, että toimeentulo on pakko turvata ennen minkään muun tarpeen tyydyttymistä. Yhteiskunnan tukiverkoston täydellinen puute korvataan lähimmäisistä muodostuneesta tukiverkostosta ja siinä liikuteltavista taloudellisista varoista ja yhteyksistä. Riippuvuus lähiverkostosta ja halu turvata mahdollisimman riskitön elämä sen jäsenille niin akuuteissa kuin kauaskantoisissa tarpeissa, ohjaavat paperittoman toimintamahdollisuuksia vielä vahvemmin vallan taloudellisten intressien palvelukseen.

\section{JOHTOPÄÄTÖKSET}

Valta vaikuttaa paperittoman toimintamahdollisuuksiin Steven Lukesin valtateorian jokaisessa ulottuvuudessa. $\mathrm{Pa}-$ perittoman toimijuutta rajoitetaan niin näkyvässä päätöksenteossa kuin pää- 
töksien tekemättä jättämisessä sekä yhteiskunnallisen mielipidevaikuttamisen kautta (Lukes 2005, 29). Vastaanottavan valtion valtaeliitti kerää taloudellisen hyödyn halvasta työvoimasta ja käyttää paperittomuusilmiötä kiistakapulana paikallisessa sekä kansainvälisessä valtapelissä. Keskustelun taustalla yhteiskunnan valta mahdollistaa paperittomien toimijuuden tarjoamalle heille joko suorasti tai epäsuorasti omia intressejään palvelevat toimintamahdollisuudet.

Rajaa virallisen ja epävirallisen yhteiskuntajärjestelmän välillä on vaikea havaita kyseen ollessa näiden kahden muodostamasta hybridimallista, jonka ohjailemana toimintamahdollisuudet ilmenevät. Virallisia sanktioita paperittomuudesta seuraa ainoastaan sanktion palvellessa valtaeliitin intressejä. Karkotusuhka osoittaa paperittoman olemassaolon reunaehdot.

Toimintamahdollisuudet ovat yhteiskunnassa jokaiselle yksilölle joltain osin rajoitettuja. Rakenteista kumpuavat toimintamahdollisuudet ja niitä turvaavat ihmisoikeudet eivät kuitenkaan näyttäydy yhdenvertaisina. Valtaeliitin intressien rajaamat toimintamahdollisuudet sekä omat ja lähipiirin tarpeet heikentävät mahdollisuutta yksilön vapaaseen kehittymiseen niin omaksi kuin yhteiskunnan hyödyksi. Tarpeiden osittainen tyydyttymättömyys vaikuttaa paperittoman kokemaan elämän mielekkyyteen ja terveyteen myös paperittomuuden mahdollisesti päätyttyä.

Tiedostamalla epätasa-arvoiset toimintamahdollisuudet ja niistä hyötyvät tahot pystymme arvioimaan mielikuviamme paperittomuutta ohjailevista valtarakenteista. Paperittomien arkea havainnoidessa vallan ulottuvuudet ovat vahvasti läsnä. Jokaista hyvinvointia tavoittelevaa toimintamahdollisuutta harkitessa on kysyttävä, kenelle tästä tulee maksaa, keiden intressejä sanktiot palvelevat? Yhtymäkohdat Steven Lukesin valtateorian $(1974 ; 2005)$ sekä Martha Nussbaumin toimintamahdollisuuksien teorian (2011) välillä paljastavat taloudellisen sekä poliittisen hyödyn, jota paperittomien toimintamahdollisuuksien ohjailulla tavoitellaan. Toimintamahdollisuuksien turvaaminen on kuitenkin ihmisoikeuskysymys. Tutkimukseni perusteella vertaukset nykyajan orjuuteen ovat oikeutettuja, sillä kansakunnan vähemmistöä edustava valtaeliitti hyötyy paperittomuusilmiön ylläpitämisestä, politisoinnista ja kriminalisoinnista. Paperittomuus yhteiskunnallisena ilmiönä näyttäytyy taloudellisen ja poliittisen hyödyn tavoittelun valossa vallan väärinkäyttönä.

\section{ViITTEET}

1 GUVM MVD, Glanoe upravlenie po voprosam migratsii, ministerstva vnutrennih del Rossijskoj federacii.

2 Moskovassa tulotaso on korkeampi kuin muualla Venäjällä. Maahanmuuttodirektoraatin työntekijä ilmoitti matalapalkkaisilla aloilla työskentelevillä asiakkaillaan kuukausipalkan olevan 350-400e/ kk (10.3.2020). Tämä palkka vastasi myös useamman tutkimukseen osallistuneen ilmoittamaa palkkatasoa.

\section{KiRJallisuUs}

Aleshkovskii, Ivan \& Grebenyuk, Aleksandr \& Kravets, Viktor \& Maksimova, Anastasiya (2019) Foreign Migrants in the Russian Labor Market: the Estimate of Their Overall Number and Their Cont- 
ribution to Russia's GDP. Economic and Social Changes: Facts, Trends, Forecast 10.15838/esc.2019.6.66.11. https://doi. org/10.15838/esc.2019.6.66.11

Aliyev, Husseyn (2013) Post-Communist informal networking: Blat in the South Caucasus. Department of Politics, University of Otago. http:// demokratizatsiya.pub/archives/21_1_ RW41W8336734714X.pdf Luettu 25.5.2020.

Abashin, Sergey (2016) Migration Policy in Russia: Laws and Debates. Teoksessa Anna-Liisa Heusala \& Kaarina Aitamurto (toim.) Migrant Workers in Russia: Global Challenges of the Shadow Economy in Societal Transformation. London: Routledge, 16-34.

BOFIT (2019) Suomen pankin siirtymätalouksien tutkimuslaitoksien viikkokatsaus 2019/27: https://www.bofit. $\mathrm{fi} / \mathrm{fi} /$ seuranta/viikkokatsaus/2019/ vw201927_1/ Luettu 29.5.2020.

Bloch, Alice \& McKay, Sonia (2016) Living on the Margins:Undocumented Migrants in a Global City. Bristol: Bristol University Press. https://doi.org/10.1332/policypress/9781447319368.001.0001

Cordell, Jake (2019) How Big Is Russia's Shadow Economy and Why Does It Matter? The Moscow Times 29.10. 2019. https://www.themoscowtimes. com/2019/10/29/big-russias-shadowinformal-economy-matter-a67817 Luettu 5.3.2020.

Emirbayer, Mustafa \& Mische Ann (1998) What Is Agency? American Journal of Sociology 103 (4), 962-1023. https:// doi.org/10.1086/231294

Gamble, Dorothy N. (2012) Well-Being in A Globalized World: Does Social Work Know How to Make It Happen? Journal of Social Work Education, 48 (4), 669-689. https://doi.org/10.5175/ JSWE.2012.201100125

Ganeeva, V. Ramilevna \& Makarova E. Vladimirovna \&, Dudochnikov \& A. Igorevich (2019) Analysis of Russian Migration Flows with socio-economic development consideration. Journal of Engineering, Management, \& Applied Sciences \& Technologies Kazan University. https://tuengr.com/ V10A/10A12HM.pdf Luettu 15.4.2020.
Gobo, Giampietro (2008). 2 method or methodology? Locating ethnography in the methodological landscape. Teoksessa Giampietro Gobo (toim.) Introducing Qualitative Methods: Doing ethnography. London: SAGE Publications Ltd, 15-32. https://doi. org/10.4135/9780857028976

Gonzales Robert (2011) Learning to Be Illegal: Undocumented Youth and Shifting Legal Contexts in the Transition to Adulthood. American Sociological Review, 76 (4), 602-619. https://doi. org/10.1177/0003122411411901

Heusala, Anna-Liisa \& Aitamurto Kaarina (2016) Migrant Workers in Russia. Global Challenges of the Shadow Economy in Societal Transformation. Routledge Contemporary Russia and Eastern Europe Series. London: Routledge. https:// doi.org/10.4324/9781315657424

Honkasalo, Marja-Liisa \& Ketokivi, Kaisa \& Leppo, Anna (2014) Moniselitteinen ja hämärä toimijuus. Sosiologia 51 (4), 365-372.

Human Rights Watch, World Report (2020) https://www.hrw.org/ world-report/2020/country-chapters/ russia\#04d1d2 Luettu 10.6.2020.

Hämeenaho, Pilvi \& Koskinen-Koivisto, Eerika (2018) Moniulotteinen etnografia (2. painos.). Helsinki: Ethnos ry.

Ife, Jim (2001) Human rights and social work: Towards rights-based practice. Cambridge: Cambridge University Press. https://doi.org/10.1017/ CBO9781139164689

Ivakhnyuk, Irina (2009) Russian Migration Policy and Its Impact on Human Development. Human Development Research Paper 14/2009.

Johnson, M.Thomas (2013) Evaluating culture: Wellbeing, institutions and circumstance. Basingstoke: Palgrave Macmillan.

Jäppinen Maija (2015) Väkivaltatyön käytännöt, sukupuoli ja toimijuus: Etnografinen tutkimus lähisuhdeväkivaltaa kokeneiden naisten auttamistyöstä Venäjällä. Sosiaalitieteiden laitos. Helsinki: Helsingin yliopisto.

Kalm-Akubardia, Maija (2019) Paperittomana lapsiperheenä Moskovassa. Idäntutkimus 26 (4), 3-17. https://doi. org/10.33345/idantutkimus. 88845 
Kara, Hanna. (2016) The makings of migrant subjectivities: time and intersectionality in the transnational everyday lives of Latin American women in Barcelona. Department of Social Research. Helsinki: University of Helsinki.

Kara, Siddharth (2017) Modern Slavery: A Global Perspective. New York: Columbia University Press. https://doi. org/10.7312/kara15846

Kaushal, Neeraj (2019) Blaming Immigrants: Nationalism and the Economics of Global Movement. New York; Chichester, West Sussex: Columbia University Press. https://doi.org/10.7312/ kaus18144

Kivisto, Peter (2017) The Trump Phenomenon. United Kingdom: Emerald Publishing. https://doi. org/10.1108/9781787143678

Kubal, Agnieszka (2020). Can statelessness be legally productive? The struggle for the rights of noncitizens in Russia. Citizenship Studies 24 (2), 1-16. https://doi. org/10.1080/13621025.2020.1720606

Ledeneva, Alena (2011) Open Secrets and Knowing Smiles. East European Politics \& Societies 25 (4), 720-736. https://doi. org $/ 10.1177 / 0888325410388558$

Ledeneva, Alena (2009) From Russia with "Blat": Can Informal Networks Help Modernize Russia? Social Research, 76 (1), 257-288.

Ledeneva, Alena (2006) How Russia Really Works: The Informal Practices That Shaped Post-Soviet Politics and Business. Ithaca [N.Y.]: Cornell University Press (Culture and Society After Socialism). http://search.ebscohost.com/login.aspx ?direct $=$ true $\& \mathrm{db}=\mathrm{e} 000 \mathrm{xww} \& \mathrm{AN}=6715$ $05 \&$ site $=$ ehost-live Luettu 27.5.2020.

Light, Mathew (2010) Policing Migration in Soviet and Post-Soviet Moscow. PostSoviet Affairs, 26 (4), 275-313. https:// doi.org/10.2747/1060-586X.26.4.275

Lukes, Steven (1974) Power: A Radical View. London: Macmillan Education LTD. https://doi.org/10.1007/978-1349-02248-9

Lukes, Steven (2005) Power:A RadicalView. 2nd edition. London: Palgrave Macmillan. https://doi.org/10.1007/978-0230-80257-5_2

Lutz, Wolfgang \& Amran, Gemma \& Bé- langer, Alain \& Conte, Alexandra \& Gailey, Nicholas \& Ghio, Daniela \& Grapsa, Erofili \& Jensen, Kathrine \& Loichinger, Elke \& Marois, Guillaume \& Muttarak, Raya \& Potančoková, Michaela \& Sabourin, Patrick \& Stonawski, Marcin (2019) Demographic Scenarios for the EU - Migration, Population and Education.

Marttila, Annamaria (2018) Tutkijan positiot etnografisessa tutkimuksessa - Kentän ja kokemuksen dialoginen rakentuminen. Teoksessa Pilvi Hämeenaho, \& Eerika Koskinen-Koivisto (toim.) Moniulotteinen etnografia (2. painos.). Helsinki: Ethnos ry, 362-392.

Max-Neef, Manfred (1992) Development and Human Needs. Real Life Economics: Understanding wealth creation. London: Routledge, 197-214.

Migrantmedia (2020) Trudovoj patent na rabotu dla bezvizovyh inostrannyh graždan v 2020 godu. https:// migrantmedia.ru/trudovoy-patentna-rabotu-dlya-inostrannykh-grazhdanposhagovaya-instruktsiya-kak-poluchitrabochiy-patent-migranta/\#Chto $\% 20$ daet $\% 20$ patent $\% 20$ na $\% 20$ rabotu $\% 20$ inostrannym $\% 20$ grazhdanam Luettu 15.4.2020.

Noll, Gregor (2010) Why Human Rights Fail to Protect Undocumented Migrants, European Journal of Migration and Law 12 (2), 241-272. https://doi. org/10.1163/157181610X496894

Nussbaum, Martha (2000a) Sex and Social Justice. New York: Oxford University Press. https://doi.org/10.1093/acprof:o so/9780195112108.001.0001

Nussbaum, Martha (2000b) Women and Cultural Universals. Teoksessa Maria Baghramian and Attracta Ingram (toim.) Pluralism: The Philosophy and Politics of Diversity. London: Routledge, 197-227. https://doi. org/10.4324/9781315824505-10

Nussbaum, Martha (2000c) Women and Human Development: The Capabilities Approach. Cambridge: Cambridge University Press.

Nussbaum, Martha (2006) Poverty and Human Functioning: Capabilities as Fundamental Entitlements. Teoksessa David B. Grusky \& Ravi Kanbur (toim.) 
Poverty and Inequality. Stanford California: Stanford University Press, 47-75.

Nussbaum, Martha (2011) Creating Capabilities: The Human Development Approach. Cambridge: Belknap Press of Harvard University Press.

Patenaude, M. Bertrand (2012) Regional Perspectives on Human Rights: The USSR and Russia, Part one - The USSR. Spice Digest. Center fo Russian, East European \& Eurasian Studies, Stanford University. https://fsi-live.s3.uswest-1.amazonaws.com/s3fs-public/ RPHR_part1.pdf. Luettu 17.3.2020.

Schenk, Caress (2018) Why Control Immigration? Strategic Uses of Migration Management in Russia. Toronto: Uni- versity of Toronto Press. https://doi. org/10.3138/9781487516352

Schultz, Liisa \& Tapio, Petri (2011) Kulutuskriittinen kohtuullisuus tarveteorioiden valossa. Alue Ja Ympäristö 40 (1), 3-16.

UN Population Division (2019) https:// www.un.org/en/development/desa/population/migration/data/estimates $2 /$ estimatesgraphs.asp?2g2 Luettu 18.3.2020.

UN Human Rights, Ratification Status for Russian Federation: https:// tbinternet.ohchr.org/_layouts/15/ TreatyBodyExternal / Treaty. aspx? CountryID $=144 \&$ Lang $=E N$ Luettu 10.6.2020. 